\title{
Conflicting Narratives of Black Youth Rebellion in Modern Britain $^{1}$
}

\author{
DrEvan Smith, \\ Department of History, Flinders University
}

\begin{abstract}
In the late 1970 s and early 1980s, several clashes between black youth ${ }^{2}$ and the police broke out in Britain. As the economic crisis of the 1970 endured and policing tactics in Britain shifted towards more confrontational means, these episodes of rebellion were seen by many in Britain as a prelude to wider revolutionary action. This article will focus on two perceptions of these rebellious acts, which provided often conflicting, but not entirely mutually exclusive, interpretations. One interpretation comes from the (primarily white) British left, who saw these rebellious youth as part of the vanguard against capitalism, a potentially revolutionary section of the working class that could provoke a broader movement against the police, the Government and the capitalist system. The other interpretation is that of radical black activists, who saw these acts of rebellion as part of a struggle by the black communities to assert a collective identity as black Britons in post-colonial Britain, while combating the racism still prevalent in Britain at the time.
\end{abstract}

This article will examine publications within these two streams to demonstrate how the episodes of youth rebellion were interpreted as acts of class or ethnicity; examining the journals of the British left, primarily those from the Communist Party of Great Britain and the Socialist Workers Party, for the former position and the journals of black activists, primarily those of Race Today, Race \& Class and the publications of the Asian Youth Movements, for the latter. The article will conclude that neither of these interpretations is wholly sufficient and that a hybrid interpretation, based on the work of postcolonial scholars, such as Homi Bhabha, is a more appropriate approach. As the thirtieth anniversary of the 1981 riots draws nearer, this approach can benefit historians as they negotiate these competing interpretations, where the events have become categorised and essentialised by leftist and black radical writers, while those who were involved in the events discussed are, in actuality, unlikely to be contained within a singular narrative.

\section{The Creation of a Multi-Cultural Britain}

Although there is a long and detailed history of black people in Britain, large-scale immigration from within the British Commonwealth began in the late 1940s, as Britain required workers to fill the acute labour shortage created by post-war reconstruction. From the late 1940 s to the mid1960s, when controls against Commonwealth immigration were introduced, hundreds of thousands of black immigrants from the Commonwealth entered Britain. ${ }^{3}$ From this time onwards, there was the creation of a consensus between the major political parties in Britain, and perpetuated by many sections within British society, that black immigration was a threat to social cohesion, with more and more controls amassed upon Britain's black population. This is what Robert Miles and Annie Phizacklea have described as the 'racialisation of British politics'.4

With the enormous pressure placed upon the ethnic minority communities in the post-war period and the racial discrimination faced by black people in many facets of their lives in Britain, a number of actions of resistance took place, on both a local and national scale, intertwining with other rebellious acts by various peoples across Britain. The 1970 s and 1980 s saw several of these actions, in the form of riots against the repressive institutions of the state (Notting Hill Carnival, Bristol, Brixton, the July 1981 riots), as well as wildcat strikes (Mansfield Hosiery Mills, Imperial Typewriters, Grunwick). Besides the general viewpoint that most of these actions were spontaneous and without precedent, both the left and black activists have attempted to place these actions into a longer historical context. 
The left have viewed these acts of rebellion as examples of a class-consciousness forming amongst the new immigrant communities. On the other hand, black activists have viewed these acts in the development of ethnic identities by the immigrant communities in response to the integrationist and exclusionist debates on 'Britishness' in the post-colonial era.

However in these debates over the historical context, the subjects - the manual worker, the unemployed youth, the local community campaigner, the housewife - are, more or less, 'silent'. Their voices are not publicised. These people were often incorporated into different structures, such as trade unions, community groups, political parties or local government organisations, but rarely given positions of authority or the opportunity to dictate any kind of policy decisions, or even the means to publicise their viewpoint. This has led to the writers of journals, from the left and black activists, to 'speak' for them, to interpret these people's actions as imbued with a definite political purpose.

\section{The British Left}

Since the 1960s, academics have debated overthe class structure of the black communities and whether black people were part of the working class. This debate has been structured within a sociologically empirical framework, which has sought to show similarities in occupation, housing, levels of income and other socio-economic factors between the white working class and the black communities. This empirical analysis had led Miles and Phizacklea to state, 'Most West Indians, Pakistanis and Indians... are structurally part of the working class'.5 For these Marxist-inspired sociologists, the major area of inquiry was how political activities in the black communities differed from the white working class and why, if there was a similar class base, did black people not make more use of the organisations of the working class, such as the trade unions, the Labour Party and the leftist groups.

In contrast, the left, particularly the Communist Party of Great Britain (CPGB) and the Socialist Workers Party (SWP)(prior to 1976, the International Socialists), immediately viewed black immigrants to Britain as part of the working class and 'fellow fighters... against the common enemy' of British imperialism and capitalism. ${ }^{6}$ While the British left was (and remains) a varied and disparate entity, this article will focus upon the CPGB and SWP. The reason for this is that the CPGB and the SWP were the largest autonomous parties to the left of the Labour Party in the 1970s and 1980s and despite any labourist or vanguardist tendencies, were involved in anti-racist activities during this period, unlike the much larger Labour Party. ${ }^{7}$

Established in 1920, the Communist Party had been a significant body within the British labour movement and a prominent anti-colonial/anti-racist organisation throughout the post-war era. ${ }^{8}$ However by the mid-to-late 1970s, the Party was at a crossroads, its membership had slumped from over 34,000 in 1964 to just over 20,500 in $1979^{\circ}$ and the Party was plagued with internal schisms. But it remained an influential leftist organisation due to its size, relative to the rest of the far left, and its publications, the daily newspaper, the Morning Star ${ }_{1}{ }^{10}$ and the monthly journal, Marxism Today. ${ }^{11}$

On the other hand, the Socialist Workers Party was a much smaller organisation than the CPGB, with membership numbers being a little over 4,000 in the late $1970{ }_{1}{ }^{12}$ but its role in the anti-fascist movement had begun to overshadow the CPGB. The IS/SWP was a Trotskyist group that grew in the late 1960 s and early $19705,{ }^{13}$ depicting itself as a revolutionary alternative to the reformist politics of the CPGB and the trade union bureaucracy. As the economic crisis worsened and their industrial ties weakened, anti-racist/anti-fascist activity became a primary concern for the SWP, taking a prominent role within the Anti-Nazi League ${ }^{14}$ and Rock Against Racism. ${ }^{15}$

The CPGB and the SWP saw unity between black and white members of the working class as evident through militant action. As the CPGB stated in a 1971 pamphlet, white and black workers were 'allies in a struggle against a common class enemy' - the bosses and the Conservative Party. ${ }^{16}$ For the left, the 
emphasis upon a united struggle by black and white working class people against the common enemy demonstrated that class-consciousness could be defined through action, rather than empirically. The riots and confrontational acts against the authority of the state have been viewed by the left as spontaneous demonstrations of an emerging class-consciousness amongst the black communities. This idea of class-consciousness roused through rebellious actions can be traced back to Lenin, who wrote that, 'riots expressed the awakening of consciousness to a certain extent'. ${ }^{17}$ But for Lenin, this was only a consciousness in 'an embryonic form', and such actions needed to be guided by a party that would 'organize... [and] become the vanguard of the revolutionary forces'. ${ }^{18}$ The CPGB and the IS/SWP both saw themselves as the vanguard party to combine the rebellious actions of the black workers with the wider struggles of the labour movement. The CPGB declared in the late 1960s, 'The Communist Party is the only political organisation that consistently opposes all manifestations of racialism and at the same time works for the ending of capitalism'. ${ }^{19}$ The International Socialists also maintained that, 'The central task we face is the building of a revolutionary socialist party... with the aim of overthrowing capitalism' that would 'unite black and white workers in this common struggle'. ${ }^{20}$

However the involvement of the left in the anti-racist movement in Britain was limited and mostly conducted on the terms of the left, often subordinated by the immediate economic issues of industrial militancy. While it was important for the left to join the fight against racism, this fight was seen as part of a wider struggle against capitalism. This position of 'class before race' had a negative effect on black people, as Trevor Carter cited:

My impression was always that the left was genuinely concerned to mobilise the black community, but into their political battles. They never had time to look at our immediate problems, so it became futile to refer to them. So blacks ended up in total isolation within the broad left because of the left's basic dishonesty. ${ }^{21}$

The left failed to effectively address the problems faced by Britain's black population and this failure saw a rise in autonomous (and confrontational) black politics.

\section{Black Radicalism in the 1970 s}

In the mid-1960s, British black politics, and wider anti-racist politics, was beginning to shift from a focus on anti-colonialism to domestic anti-racism and saw the emergence of broad-based and moderate black organisations, such as the Campaign Against Racial Discrimination, the United Coloured Peoples Association and the Institute of Race Relations. However the ineffectiveness of the official legislation, the Race Relations Act, to combat racism in British society and the increasing bipartisan consensus within the British Government that black immigrants were the 'problem' produced a more militant black political awareness, inspired by black power from the United States, Pan-Africanism and anticolonial politics in the former British Empire. Black power in Britain was partially a reaction to the dissatisfaction felt amongst black activists with the existing anti-racist organisations; a belief that the labour movement had subordinated issues of 'race' for the class struggle and that the official race relations bodies were compromised by a tendency towards conciliation, rather than effective antiracist actions. Black power - the idea that 'black people needed to redefine themselves by asserting their own history and culture to project an image which they would develop without white people ${ }^{\prime 22}$ - inspired many disaffected activists, buoyed by the actions of African-Americans in the US and the widespread cultural radicalism of the late 1960 s and early 1970 .

Black activists in Britain established their own political organisations, with the proliferation of radical publications and bookstores providing the structural centres for many black British militants. They were able to produce a number of radical publications, which advocated a black power position and often combined with a Marxist framework. These publications were often distributed out of blackowned bookstores, which became hubs for black radicals and important landmarks for the black 
communities, functioning as what Colin A. Beckles has described as 'Pan-African sites of resistance'. ${ }^{23}$ This article will focus upon two of the most prominent journals published by black radicals in Britain in the 1970s, Race Today and Race \& Class, which both emerged from the Institute of Race Relations as it became more radicalised. In addition, this will be complemented by an examination of the publications of the Asian Youth Movements (AYMs) which provide a grassroots view of black radicalism in the late 1970 .

Beginning in 1958, the Institute of Race Relations (IRR) had been established as a moderate and scholarly organisation to address 'race relations' and black politics in Britain and by the early 1970s, had two significant journals dealing with these issues - Race Today, which was a monthly magazine ${ }^{24}$ and Race, which was a academically-minded journal published quarterly. However by this time, there was an increasingly vocal section within the IRR that the Institute needed to be much more pro-active in its discussion of 'race relations', rather than merely an 'impartial' scholarly body. As A. Sivanandan, one of the major critics of the 'old' IRR and founding editor of Race \& Class, wrote:

We did not want to add to the tomes which spoke in obfuscatory and erudite language to a chosen few, we no longer believed in the goodwill of governments to listen to our reasoned arguments. ${ }^{25}$

In 1973, RaceToday became a separate entity from the IRR under the editorship of Darcus Howe, a black radical journalist, forming the Race Today Collective. Influenced by the work of Trinidadian Marxist C.L.R. James, Howe rejected the view that it was necessary to 'build a vanguard party to lead Blacks to some emancipation ${ }^{\prime 26}$ and the journal became a beacon for black political journalism, intertwining libertarian Marxism with a radical anti-racism. Max Farrar has described this position as 'black selforganisation for socialism which is autonomous of, but not cut off from, the white majority'. ${ }^{27}$ (My emphasis). Following the departure of Race Today from the IRR, the 'old' IRR shrank to three staff, who revitalised the Institute as a 'servicing station for oppressed peoples on their way to liberation'. ${ }^{28}$ The quarterly journal Race was changed to Race \& Class in mid-1974 and conceptualised as a 'campaigning journal, "a collective organizer", devoted not just to thinking... but to thinking in order to do', linking 'the situation of black workers in Britain and the liberation struggles in the underdeveloped world'. ${ }^{29}$ These journals promoted the idea that the black communities in Britain were not simply part of the British working class, but an autonomous political entity, which had different agendas, strategies, histories and points of entry to the traditional labour movement. Although an integral part of postcolonial British society, the black communities experienced 'discrimination and exclusion' in many aspects of life, which led to the development of 'networks of black people organising, primarily without the help of white people, against the racism of employers, unions, police, local authorities, political parties and others'.30 Their inspiration came partly from radical Marxism and class-based politics, but was just as informed by anti-colonial politics from Africa, the Caribbean and the Indian sub-continent, which intertwined to present a black British identity with a colonial legacy, rather than merely colonial subjects in the 'Mother Country'. This article does not assert that Race Today and Race \& Class saw ethnicity and class as completely separable entities (indeed the title Race \& Class denotes an acknowledgement of the importance of class), but their main focus was on building autonomous black working class politics, with the debut editorial of Race \& Class stating that the concern of the journal was 'the oppression of black people in Britain', primarily 'the place of black workers'. ${ }^{31}$ And importantly, in their interpretations of the episodes discussed in this article, they emphasised that these were acts of rebellion by black youth, reflecting the concerns of Britain's black communities.

The sentiment of developing a black British identity can also be seen in the Asian Youth Movements that emerged in the late 1970 s and reflected in their self-published journals, such as Kala Tara and Kala Mazdoor. As the economic crisis worsened in the mid-1970s, fascist far right parties, such as the National Front (NF) and the National Party (NP), attempted to exploit the downturn to fuel hostility towards black immigration and intimidate black people already residing in Britain. Although the NF 
contested elections, managing to record some relatively 'disturbing electoral successes', ${ }^{31}$ the main focus of the NF was now on occupying the streets and launching a campaign of intimidation, which saw an increase in violence against Britain's black population, with several deaths and 'scores of other similar incidents of unprovoked and savage racist attacks'. ${ }^{33}$

On June 4, 1976, Gurdip Singh Chaggar, a Sikh youth was stabbed to death by a gang of NF-inspired white youths in Southall.34 A reaction to this murder and increasing racial violence saw a new militancy amongst the immigrant communities with defensively militant organisations emerging, first the Southall Youth Movement (SYM) in London, then the Asian Youth Movements across Britain. The support for the traditional approach of relying on the police and the local government to act seemed to diminish as the police looked more likely to prosecute black Britons, rather than protect them. As the Bethnal Green and Stepney Trades Council wrote, 'there is considerable doubt within the immigrant community as to the interest and impartiality of the police handling complaints of racist attacks'. ${ }^{35}$ The youth of Southall now 'openly expressed their distrust of white authority and called on the community to practise self-defence'. ${ }^{36}$ The young Asian militants wanted direct action to protect themselves against racist attacks by individuals and discrimination by the authorities, rather than relying on the State. For the SYM, 'the racist attacks against young black people [made] black people feel it [was] not safe to go out at night' and after Chaggar's murder, 'whilst leaders were saying keep calm and trying to play down "isolated incidents"... [w]e knew it was time to organise ourselves'. ${ }^{37}$ Thousands of young Asians were attracted to the AYMs, who, as Anandi Ramamurthy has written, 'fought to defend their communities against fascist attacks; against police violence and racism; against the violence of state racism that separated mothers and children through increasingly tight immigration laws'. ${ }^{38}$ The AYMs published journals, such as Kala Tara, Liberation and Kala Mazdoor, which reflected this militancy; and promoted their own agenda, rather than being subsumed by the publications of the far left. The first AYM publication, Kala Tara, began in Bradford in $1979,{ }^{39}$ and was recently archived and digitised as part of the Tandana-Glowworm project. ${ }^{40}$ Kala Tara forms an important source for this article in comparison with the other black radical journals and the publications of the far left.

\section{The Militancy of Black Youth}

The clashes between the police and black youth correlate with the increasingly confrontational nature of the police in the mid-to-late 1970 s and throughout the Thatcherite era. At the heart of this confrontation was the 'criminalisation' of black youth. ${ }^{41}$ Both Afro-Caribbean and Asian youth faced many of the hardships that had been experienced by their migrant parents, but they also had grown up in Britain, which altered their experiences, particularly in terms of cultural identity and their expectations. The children of post-war black migrants had experienced similar developments in their young lives as their white contemporaries and in many ways, shared closer ties with white British society than to the culture of their parents' homeland, but were still divorced from many of the opportunities offered by a white identity. Chris Mullard wrote of this as the 'black Briton's dilemma':

He will be British in every way. He will possess understandable values and attitudes; he will wear the same dress, speak the same language, with the same accent; he will be as educated as any other Englishman; and he will behave in an easy relatable way. The only thing he will not be is white..$^{42}$

Popular racist sentiment may have demanded for immigrants to return to where they came from, but for the children of black migrants, Britain was their 'home'. The realisation that they would have to defend their right to remain where they had been for most of their lives led to a militant attitude amongst many black youth. Bhopinder Basi, a radicalised Asian youth in Birmingham, remarked, 'we started with such simple slogans as, "Here to stay. Here to fight"... Our parents may have entertained some myth of going back to the pind, but we didn't.'43 The acts of rebellion throughout the late $1970 \mathrm{~s}$ and early 1980 s were, thus in part, the violent reaction to a decade long history of harassment and 
violence against the existence of black youth in Britain.

The first generation of Commonwealth migrants were viewed as potential agents for significant political, and revolutionary, action. These migrants were not encumbered by the 'labourist' and 'economistic' approaches of the left and trade union movement ${ }^{44}$ and were, as demonstrated at strikes at Mansfield Hosiery Mills, Imperial Typewriters and Grunwick, willing to organise autonomously. At the same time, however, there was a tendency to gravitate towards the traditional non-militant community organisations, and a sense of grudging timidity to accept the conditions of migrant life coupled with some yearning to return to one's homeland. This is what Edward Said described as 'the paradox of the exile', where the 'positive benefit of challenging the system' by the migrant's position was always countered by a de-habilitating sense of loss and exclusion - 'between the old empire and the new state'. ${ }^{45}$

Some on the left felt that the sense of exile and entrapment between two cultures would also exist in the second generation of black Britons. In a 1974 discussion of youth culture in the CPGB journal MarxismToday, Imtiaz Chounara claimed that 'most young coloured people are caught in between two cultures - that of Britain and that of their parents'..$^{66}$ Chounara appealed for the CPGB to incorporate black youth (not just black workers in the industrial sector) into the Party, to counter the appeal of 'black power', which the CPGB believed to share an affinity with 'deviant' versions of Marxism, such as Maoism and Trotskyism. ${ }^{47}$ Chounara suggested:

We must therefore fight for black youth to mix culturally with white youth but at the same time to retain their own cultural identity. This is an important part of the fight for black consciousness - to get respect for black people and their culture, not only amongst young white people but also amongst black people themselves. This cannot be done in a "black power" manner, putting black above white, but in a true Marxist manner, fighting for the rightful place of black workers alongside their white brothers as equals. $4^{8}$

However the CPGB had to compete with other groups on the far left, such as the IS/SWP, and radical black activists, who both saw black youth as a far more positive force for revolutionary political action. For them, black youth were deemed to have the same divorced position from the organised labour movement, but were less closely associated with the traditional organisations of the black communities and more likely to be involved in militant actions. This willingness to confront the perpetrators of racial violence and the state led many to idolise their spontaneity and militancy. Ian Macdonald declared in Race Today that black youth were 'the vanguard of a world-wide proletarian movement'. 49 Cathie Lloyd points to the fetishisation of the rebellion of black youth seen through The Clash's punk song White Riot, which 'expressed admiration for combative black youth at [the

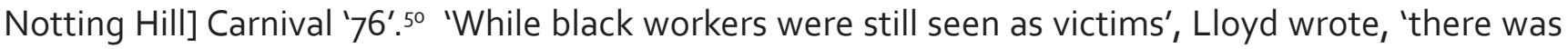
also admiration and a feeling that they [especially black youth] were at the forefront of a challenge to the established social order'. ${ }^{51}$

For the IS/SWP, the revolutionary potential of black youth was realised as their acts of rebellion, such as the Notting Hill Carnival riot in August 1976 and the formation of the Southall Youth Movement, coincided with the Party's campaign strategies. In a 1976 internal bulletin, the Party declared that 'the twin themes of fighting racialism and fighting for the right to work now dominate our immediate perspective', ${ }^{22}$ attempting to incorporate those affected by racism and unemployment, which were both experienced by black youth. Acts like the riot at the Notting Hill Carnival were seen by the IS/ SWP as the beginning of a series of events that 'highlighted the question of the political role of black youth', where the seemingly spontaneous rebellion presented 'new opportunities' for socialists. ${ }^{53}$ Tony Bogues, in the journal International Socialism, defended the actions of those at the Carnival as not mere lawlessness or the deeds of the 'lumpenproletariat', declaring that these youth were 'part of the strata in the working class that is exploited and oppressed'. ${ }^{54}$ 
The same sentiment was expressed in the relationship between the IS/SWP and the Asian Youth Movements. The IS/SWP celebrated the creation of the Southall Youth Movement as the 'inevitable conclusion to the spontaneous youth movement' that emerged from the anger against the racist attacks occurring at the time, which was independent of any leftist intervention. 55 John Rose wrote in International Socialism that the formation of the SYM 'took the entire local left by surprise', writing that they had 'already given chase to the racists on the streets... and ultimately they will give the racists chase in the factories'. ${ }^{6}$ However the IS/SWP felt that the 'only long-term chance that the SYM has for growth and development is if the leadership comes to decisively adopt revolutionary socialist politics'.57

The AYMs experienced difficulties in maintaining their own identities when dealing with the left, with the leftist groups often depicting the AYM campaigns as unorganised and lacking leadership. Balraj Puriwal, explained:

Every time we tried to protest and give our own identity the left tried to take it over... they gave us their slogans and placards... our own identity was subsumed, diffused and deflected..$^{58}$

There was sympathy for the left amongst those involved in the AYMs, but not at the substitution of their own identity. As Nermal Singh wrote:

The white left tell us only the working class as a whole will be able to smash racism by overthrowing capitalism and setting up a socialist state.

This maybe so, but in the meantime are we, as one of the most oppressed sections of the working class, to sit by idly in the face of mounting attacks. No! We must fight back against the cancerous growth of racism..$^{59}$

Tariq Mehmood, part of the AYM in Bradford, expressed a similar critique about the interventionist tendencies of the organised left in the political actions of black youth, 'I wanted a socialist world... [but what] I understood by socialism... [were] things different to my white colleagues'. ${ }^{60}$

While the left, radical black activists and black youth continued to interact with each other, to varying degrees, throughout the late 1970 s and early 1980s, this already tenuous relationship became more fractured after the 1979 General Election, as the left's anti-fascist campaign, which had brought the greatest amount of interaction between the left and Britain's black communities, declined after the electoral defeat of the National Front. Although the explicit fascism of the National Front had been curtailed, racism was still a widespread phenomenon in British society. Britain's black communities still faced many problems - harassment by the police, much higher unemployment rates under the Conservatives, continuing racial discrimination in the workplace, housing and social services and further restrictions on citizenship under the 1981 British Nationality Act. But most of the British left, already demoralised by the electoral victory of Thatcher and the amount of trade unionists who voted Conservative, seemed to focus on the distinctly class-orientated aspects of Thatcherism and promoted a traditional and industrial-based response. That is, until the summer of 1981, when riots broke out across the inner cities of Britain.

\section{The 1981 Riots as Social Protest}

The first term of Margaret Thatcher's Prime Ministership saw extensive rioting by black youth, first in Bristol in 1980, then in Brixton and across Britain in 1981. For commentators, academics and activists on the left and within the black communities, these riots have been viewed as either part of a wider malaise by the lower classes against the neo-liberal policies of Thatcherism, or the unstructured 
reaction by black youth to years of racial harassment and discrimination that continued on from the black struggles of the 1970 .

For the left, the 1981 riots were indicative of a widespread antipathy towards the socio-economic policies of the Conservative Government, which saw a reaction by the 'most oppressed group in the inner city areas' - black youth - who 'drew into the struggle the slightly less oppressed' - white youth. ${ }^{61}$ The Communist Party stated that the riots were 'explosive' reactions to long term problems in the inner cities, the 'deep crisis affecting [the economy] since the 1970 s and the 'particular consequences of Thatcher's policies'. ${ }^{62}$ As black youth were amongst the most affected by these economic conditions, coupled with the more immediate burdens of police harassment and the impact of institutional racism, they were the most likely to react, albeit in a manner that was outside the organisation of the left. As the CPGB stated, 'Anarchically - yes. Negatively - yes. Individualistically - yes. But nonetheless in struggle'.63

The SWP were adamant that the 1981 riots were 'class riots' and not 'race riots'. ${ }^{64}$ Colin Sparks stated the riots were the work of 'a mainly working class community against the symbols of oppression and deprivation'. ${ }^{65}$ The riots were the 'common result of unemployment and crisis', exacerbated by the experience of racism and the unequal distribution of economic hardship upon black youth. ${ }^{66}$ What demonstrated the class aspect of the riots was, Chris Harman wrote, the fact that in virtually all the British riots there has been significant white involvement alongside blacks, and the involvement has not just been of white leftists, but of white working class youth'. ${ }^{67}$ For Harman, the 'immediate background of the riots lies... in a huge increase in unemployment', ${ }^{68}$ with the result being a common experience of repression and economic hardship that contributed to the lower class rebellion. Harman portrayed the riots as a modern incarnation of previous rebellions by the lower classes in Britain. While there was a strong narrative of resistance flowing from the black industrial struggles of the 1970s and the disturbances at Notting Hill and Bristol, Harman linked the riots to previous unemployment struggles in 1886-87 and in 1931-32. ${ }^{69}$ For the left, the riots were seen as a starting point for resistance to Thatcherism. The SWP declared that the riots were the symptoms of a 'bitterness brewing... from the experience of Tory government and economic crisis', which would 'sooner or later... explode in the factories as well as on the streets'. ${ }^{70}$ It was up to socialists to 'seize the opportunities to build unity in struggle ${ }^{\prime 71}$ that would present themselves as Thatcherism emboldened its attacks upon the 'subversive' elements of society.

While not denying the common economic causes of the riots or the involvement of white youth, black activists and journalists emphasised the role of black youth and the racial discrimination and harassment experienced by the black communities that were integral factors in the outbreak of the rioting. For the journal Race \& Class, the reasons for the riots were clear, quoting a black youth interviewed for the SundayTelegraph: 'It is not against the white community, it's against the police'..$^{72}$ The journal emphasised the repressive nature of the police and the continual harassment faced by black people in everyday life. The repeated harassment by the police formed a long narrative that heightened with the events of the late 1970s, before exploding with the riots of the early 1980s. The journal tried to emphasise the continuity between the events, stating, 'In many ways what happened during and after the 1976 Carnival was a premonition of the later "riots"'.73

The journal also drew a historical continuity between the hundreds of racial attacks that had occurred since the mid-1970s - a process through which black people were 'attacked,... criminalised... and rendered second-class citizens' - and the rioting. Such riots represented a violent response against the racists and the police, who had failed to adequately protect the black communities. ${ }^{74}$ Quoting the Hackney Legal Defence Committee, the journal portrayed the riots as the long awaited reaction to this continual racism: 
Black youth took to the streets to defend our communities against police and racial violence. From Brixton to Toxteth, Moss Side to Southall black youth said: "No more: enough is enough!"75

Both Race \& Class and Race Today portrayed the riots as the result of a lack of a political voice for Britain's black communities in conventional party politics. As A. Sivanandan was quoted, 'The black community is a community under attack and, increasingly, a community without redress'. ${ }^{76}$ Looking at the political situation for black Britons throughout the 1970 and the early 1980 , both journals saw black communities attempting to work within the system, but still facing exclusion - from the mainstream political parties, trade unions, local government and the left, amongst others. The journals believed this exclusion had burst into spontaneous acts of rebellion. The riots were a forceful recognition of the limited space in which black people in Britain could enter the political sphere, as well as an unplanned reaction to years of racial discrimination, police harassment, violence and economic hardship. The left and black activists recognised that these riots had a political dimension, but there was disagreement as to whether this dimension was characterised by notions of 'class' or 'race'.

\section{The Influence of 'History From Below'}

Both the leftist and black radical writers were influenced by the theory of 'History from Below', which was developed by Marxist historians such as E.P. Thompson, Eric Hobsbawm and George Rudè, to demonstrate that these acts of rebellion by black youth in the 1970 s and 1980 s had a distinct political significance that fitted into wider histories of rebellion rather than being mere wanton displays of destruction. As Harvey Kaye has noted, the major purveyors of 'history from below' had a 'decided emphasis on resistance and rebellion', demonstrating that these acts of resistance were not 'merely apolitical hysteria, criminal activity or deviance'. 77 In understanding the acts of rebellion that happened in the 1970 s and 1980s, the left and black activists used history to demonstrate the wider context as to why these actions had taken place and to emphasise that they were not 'something new and sinister in [a] long national history', as MP John Stokes had described the Brixton riots of $1981 .{ }^{78}$ However the left and black activists disagreed on the political outlook and historical lineage of these acts. For the left, the rebellious actions were placed in a narrative of the common people and class struggle in British history. For black activists, they were part of a history of black people attempting to assert their place within a post-colonial Britain, resisting the discrimination and hostility they faced and taking inspiration from the colonial struggles in their home countries, as well as from radical politics in Britain.

Commentators from both sides evoked the work of Marxist historians to demonstrate that these acts were part of a wider history of rebellion. In Race \& Class, Frances Webber portrayed the riots as part of a long history of lower class revolt against the ruling classes and the state, beginning with the Peasants' Revolt of 1381 and recounted numerous rebellions throughout British history up to the 'Battle of Cable Street' in 1936. Like these previous occurrences, the 1981 riots had been preceded by the disillusionment of part of the lower class, tired of being harassed and excluded, without access to the official political discourse. As Webber explained:

Riot and revolt has been, for the past six centuries, a traditional way of expressing and redressing the grievances of the poor and the powerless - a method of last resort, after petitions and pleas had fallen on deaf ears. ${ }^{79}$

In their major study of the 1980 Bristol riot, Harris Joshua and Tina Wallace, fellow travellers of and contributors to Race \& Class, saw the work of Hobsbawm, Rudè and Thompson as 'powerful support' for the view that riots, as the focus of 'collective violence', could be identified as the 'political struggle and protest conducted by ordinary people in pursuit of identifiable and agreed goals'. ${ }^{80}$ They saw a connection with the 'violent crowds of 18th Century England' and quoted Hobsbawm at length on the 
political aspect of popular rebellion:

The classical mob did not merely riot as protest, but... expected to achieve something by its riots... For the mob was not simply a casual collection of people united for some ad hoc purpose, but in a recognised sense, a permanent entity, even though rarely permanently organised as such. ${ }^{81}$

In the Communist Party journal MarxismToday, George Rudè himself wrote an article on the similarities between the 1981 riots and those that occurred during the French Revolution and the revolutions of 1848 , stating, '[t] here is no question, of course, but that riots, whether today's or those of preindustrial times, have much in common' ${ }^{82}$

While it is useful to adapt the methodologies and approach of the British Marxist historians' work on eighteenth and nineteenth century labour history to the modern struggles of black Britons, it is problematic to see these struggles as merely part of a continuous narrative of lower class rebellion in Britain. A significant reason for this is that this narrative would reduce or obscure the important colonial origins of 'race relations' in Britain and how the colonial project informed how the white working class related to black workers, with many black activists seeing the colonial hierarchy replicated in domestic labour politics. ${ }^{83}$

Another reason for the problems of a continuous narrative is that one may assume that political motivations or formation of identities are in some way a-historical or static. Social historians, like those involved in progressive politics in the last thirty years, have had to negotiate the essentialism of identity and class politics, where different groups have attempted to form contained narratives to construct an exclusive identity. Those involved in the black struggles of the 1970 s and 1980s did not entirely act out of working class solidarity or identify exclusively as a member of a black ethnicity, with experiences of both class and race informing their actions. Any attempt by the left or by black radical activists to reduce the actions of those involved in the riots, uprisings and revolts of the late 1970 and early 1980 s to distinctly separate narratives based on class or ethnicity would neglect the complexities of those involved in the struggles.

\section{Bhabha and the Hybrid Nature of Popular Rebellion}

Homi Bhabha has addressed how popular rebellion is contextualised by certain groups seeking to claim 'ownership' over the political consciousness of those involved in the rebellion. Political positions, such as class-based politics and those based around ethnicity, cannot claim total possession of popular rebellion. The reason for this need to identify rebellious actions within an essential political framework is, as Bhabha states, 'because there is no given community or body of the people whose inherent, radical historicity omits the right signs'. ${ }^{84}$ The construction of competing narratives by the left and black activists demonstrate there is no 'pure avenging angel speaking the truth of a radical historicity' ${ }^{185}$ and the categorisation of popular struggle into one position, of either class consciousness or ethnic identity, negates the fact that the motives of all those involved are never identical. As Bhabha states:

Our political referents and priorities - the people, the community, class struggle, anti-racism, gender difference, the assertion of an anti-imperialist, black or third perspective - are not there in some primordial, naturalistic sense. Nor do they reflect a unitary or homogeneous political object. They... are always in historical or philosophical tension, or cross-reference with other objectives. ${ }^{86}$ (My emphasis)

In the history of popular struggle, the objectives and intentions of those involved is 'neither the one nor the other' and is always contested. ${ }^{87}$

The concept of hybridity has been developed by numerous scholars over the last twenty years, such as Pnina Werbner and Tariq Modood, who have skilfully used the term 'cultural hybridity' to analyse 
the status of ethnic communities in multi-cultural Britain. ${ }^{88}$ However within their analysis, the term seems to implicitly suppose that identity, while not essentialised as either black nor white or AfroCaribbean nor Asian nor English (and so forth), is still significantly determined by ethnicity, albeit in hybrid forms. Ramamurthy uses this notion of 'cultural hybridity' in her article on the AYMs, describing the culture of the AYMs as a hybrid culture, 'encouraging co-operation between the various nationalities of the [Indian] sub-continent', tied to a recognition that they were not merely Asian migrants in Britain, but deeply 'rooted in Britain'. ${ }^{89}$ Nevertheless, Ramamurthy's use of 'cultural hybridity' still seems to assume the primacy of ethnicity in the politics of the AYMs. Bhabha's notion of hybridity is a useful theoretical tool for analysing the acts of rebellion and resistance explored in this article as it moves beyond the framework of 'cultural hybridity', outside interpretations based on ethnicity (even in hybrid forms) and/or class. Nikos Papastergiadis has noted that a number of scholars, such as Gayatri Spivak, have criticised the notion of hybridity for glossing over divisions caused by class, gender and ethnicity, ${ }^{90}$ however the notion is used within this article not to gloss over divisions, or homogenise the history of these episodes of rebellion and resistance, but used to highlight (and unravel) the essentialisms embedded within the traditional narratives of these events. In the history of post-colonial Britain and the struggles of its black communities, Bhabha's concept of hybridity can be an effective tool in analysing the interpretation of popular rebellion by the left and of black activists, taking into account that these actions were not just the latest in a long history of lower class rebellion nor merely episodes in the formation of an ethnic identity in Britain, or even the direct continuation of anti-colonial resistance in the post-colonial sphere.

Since the time period discussed in this article, there have been further spontaneous acts of rebellion and resistance by Afro-Caribbean and Asian youth in Britain, significantly in clashes between Asian youth, the police and fascist agitators in Oldham and Bradford in 2001. Although several of the organisations and publications discussed in this article are no longer present, the divergence in contemporary modes of interpretation, primarily constructed around ethnic or class-based identities, are very similar to the narratives created in the 1970 s and 1980 s. Similar to the analysis by Chris Harman and Colin Sparks for the SWP of the 1981 riots, Hassan Mahamdallie in the SWP journal Socialist Review, emphasised the class aspects of the riots in Oldham and Bradford in 2001, that the 'principal roots of the riots lay in the decades-long economic decline of those ex-milltowns, and the all-encompassing poverty that bred resentment and fed hostility.'. ${ }^{11}$ On the other hand, the journal Race \& Class focused on the riots as a reaction by young Asians in the north of England to concerns specific to them, which:

signalled the rage of young Pakistanis and Bangladeshis of the second and third generations, deprived of futures, hemmed in on all sides by racism, failed by their own leaders and representatives and unwilling to stand by as, first fascists, then police officers, invaded their streets..$^{92}$

For Arun Kundnani, the riots of 2001 were distinctively a response by young working class Asians, primarily young Muslim males, who had grown up in Britain, 'discarded for their class, excluded for their race, stigmatised for their religion, ghettoised and forgotten'. ${ }^{93}$ A comparable process of categorisation of either 'race' or class can be seen in how these organisations and publications interpreted the acts of rebellion and resistance in the 1970s-1980s and in the twenty first century. Using Bhabha's notion of hybridity, contemporary historians should recognise that just as 'neither the one nor the other' are wholly satisfactory to explain the events of thirty or so years ago, analysis of the events of recent times should also recognise the tension between the contested narratives.

\section{Conclusion}

For historians analysing the clashes between black youth and the institutions of the state in the late 1970 and early 1980s, it is important to look at how these events were interpreted in the radical press at the time. Unlike the mainstream media, the journals discussed in this article showed that far from being random acts of vandalism and violence, the acts of rebellion had specific political characteristics. 
However as demonstrated in this article, these political characteristics were disputed and the acts were seen as parts of wider, and differing, narratives of political struggle. For the left, they were the latest incidents in the history of lower class rebellion in Britain and the black youth involved were viewed as potential revolutionaries that could be integrated into the class struggle. For black radical activists, these acts were episodes of resistance by black communities against the pervasive nature of racism in British society and a robust promotion of a resilient and autonomous black British identity.

While these interpretations are very useful for historians of post-colonial Britain, it is important to recognise that these often conflicting interpretations can only provide part of the history. Commentators from the left and black radical press have sought to encompass those involved in the riots, the clashes and the uprisings into their own political spheres, but this overlooks the fact that not everyone involved would have had clearly identifiable political motivations or motives that can be categorised by either class or ethnicity. The idea of hybridity, developed by scholars such as Homi Bhabha, can be useful in negotiating between the interpretations, recognising that people and events can reflect a multitude of differing and conflicting ideas and/or motives. The leftist and black radical interpretations, presented in the publications of the CPGB , the IS/SWP and the journals of Race \& Class and Race Today, as well as those of the Asian Youth Movements, are important for understanding the history of black youth rebellion in modern Britain, but historians should acknowledge the limitations their interpretations and the complex political nature of these events.

\section{References}

1. This article is based on a paper presented at the Social History Society Annual Conference, held in Rotterdam in late March 2008. I would like to thank Matt Fitzpatrick and the attendees of the Flinders University Department of History Seminar Series for their comments on previous versions of this article.

2. The term 'black' is used in this article to describe both Afro-Caribbeans and South Asians as in most of the literature from the period studied, this is the term used, although it is recognised that the use of this term does not allude to a homogenous community between non-white Britons. The term 'Asian' is used in this article to describe South Asians from the Indian sub-continent, primarily those of Indian, Pakistani and Bangladeshi origin. See: Fryer, Peter. Staying Power: The History of Black People in Britain. London: Pluto Press, 1984; Ramdin, Ron. The Making of the Black Working Class in Britain. Aldershot: Ashgate, 1987; Goulbourne, Harry. Aspects of Nationalism and Black Identities in Post-Imperial Britain, in Cross, Malcolm. \& Keith, Michael. (eds), Racism, the City and the State . London: Routledge, 1993, pp. 177-192; Kalbir Shukra, The Changing Pattern of Black Politics in Britain. London: Pluto Press, 1998; Satnam Virdee, England: Racism, Anti-Racism and the Changing Position of Racialized Groups in Economic Relations, in Gareth Dale, G. \& Cole, Mike. (eds), The European Union and Migrant Labour. Oxford: Berg Publishers, 1993, pp. 69-89.

3. For figures, see: Hansard, 18 March, 1965, col. 311-312; Hiro, Dilip. Black British, White British: A History of Race Relations in Britain. London:Paladin, 1992, p. 331.

4. Miles, Robert \& Phizacklea, Annie. White Man's Country: Racism in British Politics. London: Pluto Press, 1984, p. 38.

5. Miles, Robert. and Phizacklea, Annie. Class, Race Ethnicity and Political Action. Political Studies, 25(4), December 1977, p. 491.

6. Pollitt, Harry. Britain Arise. London: Communist Party, 1952, p. 18.

7. Militant, although a significantly large leftist group during this period, will not be discussed. This is because Militant were still an entrist group within the Labour Party at this stage and were not overtly involved in any major anti-racist campaigning, often rejecting any involvement with broad-based antiracist movements like the Anti-Nazi League. See: Crick, Michael. Militant. Trowbridge: Faber and Faber, 1984, p. 72.

8. The Communist Party of Great Britain was formed in 1920 by several socialist and labour groups inspired by the Bolshevik Revolution of 1917 and from the 1930s onwards, it was the largest political party to the left of Labour. The Party was heavily involved in numerous labour movement campaigns throughout the inter-war period, primarily the Anti-fascist and Unemployed Workers Movements, which brought it a high level of support in the late 1930 and during the Second World War. However the Party was steadfast 
in its support for the Soviet Union (and Stalin during his time in power), which proved a hindrance in the Cold War era. The CPGB was a significant force in the trade unions during the industrial militancy of the late 1960 s and early 1970s, but was unable to maintain this level of support, as other leftist groups and new social movements competed for influence. After a series of internal schisms and declining membership numbers during the 1970 and 1980 , the Party dissolved itself in 1991. See: Thompson, Willie. The Good Old Cause: British Communism 1920-1991. London: Pluto Press, 1992; Eaden, James, \& Renton, David. The Communist Party of Great Britain since 1920. Houndmills: Palgrave Macmillan, 2002; Andrews, Geoff. Endgames and New Times: The Final Years of British Communism 1964-1991. London: Lawrence And Wishart Ltd, 2004.

9. Thompson (ref. 8, p. 218)

10. The Morning Star began as The Daily Worker in 1930 (changing its name in 1966) and remains the only daily paper of the left in Britain. Despite the transference of ownership from the Communist Party to the People's Press Printing Society in 1946, the paper 'remained the acknowledged voice of the CP until the factional disputes' of the 1980s. It is currently aligned to the Communist Party of Britain (CPB), which was established by a splinter group from the CPGB in 1988. See: Morgan, Kevin. The Communist Party and the Daily Worker 1930-1956, in Andrews, Geoff, Fishman, Nina \& Morgan, Kevin (eds). Opening the Books: Essays on the Social and Cultural History of the British Communist Party. London: Pluto Press, 1995, pp. 142-159; Beckett, Francis. Enemy Within: The Rise and Fall of the British Communist Party. London: John Murray Publishers Ltd,1995, pp. 190-211.

11. Marxism Today was the chief theoretical journal of the CPGB, launched in 1958 to maintain order in the Party's theoretical debates. From 1962 until 1977, loyal Party member and official historian of the CPGB, James Klugmann was editor of the journal until his retirement. In 1977, Martin Jacques, a leading reformer within the Party, took over the helm and used the journal to regenerate debate amongst the left in the 1980s, which included an embrace of new social movements and calls for the re-evaluation of the CPGB's emphasis on labourist politics. See: Pimlott, Herbert. From the Margins to the Mainstream: The Promotion and Distribution of Marxism Today, Journalism, 5(2), 2004, pp. 203-226; Pimlott, Herbert, Write Out of the Margins: Accessibility, Editorship and House Style in Marxism Today, 1957-91, Journalism Studies, 7(5), 2006, pp. 782-806; Jacques, Martin, Introduction, Marxism Today Archive [Online]. May 2006. (Retrieved January 30, 2010). (Url http://www.amielandmelburn.org.uk/collections/mt/index_ frame.htm).

12. Mcllroy, John. "Always Outnumbered, Always Outgunned": The Trotskyists and the Trade Unions, in Mcllroy, John, Fishman, Nina \& Campbell, Alan (eds), British Trade Unions and Industrial Politics vol II: The High Tide of Trade Unionism, 1964-79. Aldershot: Ashgate, 1999 p. 285.

13. The IS/SWP was a Trotskyist group based around the ideas of Tony Cliff, which rejected the orthodox Trotskyist notion that the Soviet Union was a 'degenerated workers' state', instead claiming that the Soviet Union had created 'state capitalism'. Initially buoyed by the radicalism of 1968 , the IS moved away from student radicalism and reorganised as a Leninist group, enthused by the industrial militancy of the early 1970s. Membership steadily increased between 1968 and 1974 as the International Socialists depicted itself as a revolutionary alternative to the CPGB, although it was still much smaller than the CPGB. In late 1976, the group changed its name to the Socialist Workers Party, although its worker membership was still minimal. Its involvement in the Anti-Nazi League and the Right to Work campaign saw its influence grow in the 1970 s and early 1980 s. With the collapse of the CPGB in 1991, the SWP was able to present itself as the primary left-wing group in Britain. Over the last 15 years, it has been an influential organisation of the British left, chiefly in the Stop the War campaign against the Iraq War and the short-lived electoral successes of Respect. See: Birchall, lan. The Smallest Mass Party in the World: Building the Socialist Workers Party, 1951-1979. London: Socialist Workers Party, 1981; Callaghan, John. The Far Left in British Politics. Oxford: Wiley Blackwell, 1987, pp. 84-112; Higgins, Jim. More Years for the Locust: The Origins of the SWP. London: I Group, 1997; Cliff, Tony. A World to Win: Life of a Revolutionary. London: Bookmarks, 2000; Smith, Murray. Where is the SWP Going?, International Socialism, 2(97), Winter 2002, pp 39-48; Steel, Mark. What's Going On? The Meanderings of a Comic Mind in Confusion. London: Simon and Schuster Ltd, 2008.

14. The Anti-Nazi League (ANL) was established in 1977 by several SWP members and Labour left MPs to counter the electoral presence of the fascist National Front. One of the largest mass movements in British history, it was highly successful in disseminating the idea of NF as 'Nazis'. After the NF's dismal results in the 1979 General Election, the ANL started to diminish and finally wound up in 1981. See: Copsey, Nigel. Anti-Fascism in Britain. Basingstoke: Palgrave Macmillan, 2000; Renton, David. When We 
Touched The Sky: The Anti-Nazi League 1977-1981. Cheltenham: New Clarion Press, 2006; Smith, Evan. A Bulwark Diminished? The Communist Party, the SWP and Anti-Fascism in the 1970s. Socialist History Journal, 35, 2009, pp. 59-80.

15. Rock Against Racism (RAR) was a sister organisation to the ANL, started in 1976 by a number of IS/SWP members to combat racist attitudes amonst young people, primarily using the 'new' musical styles of punk and reggae. The ANL and RAR organised several festivals and hundreds of shows between 1976 and 1981 to promote the anti-racist message, described by Stuart Hall in Marxism Today in 1979 as 'one of the timeliest and best constructed of cultural interventions'. Hall, Stuart. The Great Moving Right Show, Marxism Today, January 1979, p. 15. See: Widgery, David. Beating Time: Riot ' $n$ ' Race ' $n$ ' Rock ' $n$ ' Roll. London: Chatto and Windus, 1986; Frith, Simon. \& Street, John. Rock Against Racism and Red Wedge: From Music to Politics, from Politics to Music, in Garofalo, Reebee (ed.) Rockin'The Boat: Mass Music and Mass Movements. Boston: South End Press, 1992, pp. 67-80; Kalra, Virinder S. Hutnyk, John \& Sharma, Sanjay. Re-Sounding (Anti)Racism, or Concordant Politics? Revolutionary Antecedents, in Sharma, Sanjay, Hutnyk, John \& Sharma, Ashwani (eds), Dis-Orienting Rhythms: The Politics of New Asian Dance Music. London: Zed Books Ltd, 1996, pp. 127-155; Sabin, Roger. "I Won't Let That Dago By": Rethinking Punk and Racism, in Sabin, Roger. Punk Rock: So What? The Cultural Legacy of Punk. London: Routledge, 1999, pp. 199-218; Gilroy, Paul. There Ain't No Black in the Union Jack: The Cultural Politics of Race and Nation. London: Routledge, 2002, pp. 151-177; Goodyer, lan. Crisis Music: The Cultural Politics of Rock Against Racism. Manchester: Manchester University Press, 2009.

16. Bellamy, Joan. Unite Against Racialism: Defeat the Immigration Bill. London: Communist Party of Great Britain, 1971, p. 10; p. 9.

17. Lenin, V.I. What is to be Done? Peking: Progress Publishers, 1978, p. 37.

18. Lenin, V.I. (ref. 17, p. 38; p. 111) Italics are in the original text.

19. CPGB London District Committee. Win the Battle Against Racialism with the Communists, London: CPGB, n.d., CP/LON/RACE/02/06, Labour History and Study Centre, Manchester (hereafter LHASC), (flyer).

20. Caffoor, Mike. The Fight Against Racialism. London: Pluto Press, 1972, pp. 18-19.

21. Cited in, Carter, Trevor. Shattering Illusions: West Indians in British Politics. London: Lawrence and Wishart Ltd, 1986, p. 140; Italics are in the original text.

22. Shukra, Kalbir. From Black Power to Black Perspectives: The Reconstruction of a Black Political Identity. Youth and Policy, Summer 1995, p. 6.

23. Colin A. Beckles, Colin A. "We Shall Not Be Terrorised Out of Existence": The Political Legacy of England's Black Bookshops. Journal of Black Studies, 29(1), September 1998, p. 51.

24. Race Today was first published by the IRR in 1969 until the Race Today Collective broke away in 1973. From this time until the mid-1980s, the magazine was under the editorship of Darcus Howe. Leila Hassan took over editorial duties in 1985, but the magazine and the Collective folded in 1988. The George Padmore Institute in London and the Working Class Movement Library in Salford hold archival material of the magazine and the Race Today Collective.

25. Sivanandan, A. Race and Resistance: The IRR Story, Race \& Class, 50(2), 2008, p. 28.

26. Howe, Darcus. interviewed by Lawrence, Ken. in Buhle, Paul (ed.), C.L.R. James: His Life and Work. London: Allison and Busby, 1986, p. 147.

27. Farrar, Max. "You Don't Have to Have Read James to be a Jamesian": Preliminary Notes on the relationship Between the Work of CLR James and Some of the Radical Black, Anti-Racist and Left Movements in the UK, 1970 s to 1990s, [Online]. St Augustine: CLR James Centennial Conference, 20-23 September, 2001, (Retrieved 14 July, 2009). p. 9. (Url http://www.maxfarrar.org.uk/docs/ CLRJamesPaperUnivWl2001.pdf). (Paper)

28. Sivanandan (ref. 25, p. 28)

29. Editorial Working Committee. Editorial. Race \& Class, 16(3), 1975, p. 232; p. 231.

30. Shukra, Kalbir. The Death of a Black Political Movement. Community Development Journal, 32(3), July 1997, p. 233.

31. EWC (ref. 29, p. 231)

32. Copsey, Nigel. Anti-Fascism in Britain. Basingstoke: Palgrave Macmillan, 2000, p. 123.

33. Bethnal Green and Stepney Trades Council. Blood on the Streets: A Report by Bethnal Green and Stepney Trades Council on Racial Attacks in East London. London: Bethnal Green and Stepney Trades Council, 1978, p. 4. Alongside the hundreds of acts of racist violence in the late 1970s, Peter Fryer calculated that there were thirty-one racist murders committed between 1976 and 1981. Fryer, P. Staying Power: The History of Black People in Britain. London: Pluto Press, 1984, p. 395. 
34. Hiro (ref. 3, p. 169); Renton, D. (ref. 14, p. 139)

35. Bethnal Green and Stepney Trades Council (ref. 33, p. 9)

36. Hiro(ref. 3, p. 17)

37. Purewal, Bahai. cited in, Against Racism in Southall, Challenge, 36, August/September 1976.

38. Ramamurthy, Anandi. Archiving the History of a Social Movement: Tandana-Glowworm, the Asian Youth Movements Archive. South Asian Cultural Studies, 1(1), 2006, p. 14.

39. Ramamurthy, Anandi. The Politics of Britain's Asian Youth Movements. Race \& Class, 48(2), 2006, p. 48.

40. The Tandana-Glowworm project is a digitised archive of the ephemera of the Asian Youth Movements, presenting the history of the AYMs from the late 1970 s to the mid-1980s. The AYMs started to divide and dissipate in the mid-1980s, as the 'broad-based black political identity that they had embraced began to lose influence', with Islam becoming a more attractive form of identity politics for many, but also alienating others in the process. As Ramamurthy has written '[b]y 1989, the Rushdie affair was to drive activity along explicitly religious lines'. Ramamurthy, A. (ref. 39, p. 57)

41. See: Gilroy, Paul. The Myth of Black Criminality. Socialist Register, 1982, pp. 47-56; Gutzmore, Cecil. Capital, "Black Youth" and Crime, Race \& Class, 25(2), 1983, pp. 13-30.

42. Mullard, Chris. Black Britain, London: Allen and Unwin, 1973, p. 145.

43. Basi, Bhopinder. cited in Ramamurthy, Anandi. Kala Tara: A History of the Asian Youth Movements in Britain in the 1970 s and 1980s, Second Generation Asians Resisting Racism Project. [Online], Preston, 2007, (accessed 14 March, 2007), p. 18, (Url: http://www.tandana.org/pg/resources).

44. Cambridge, A. X. \& Gutzmore, C. The Industrial Action of the Black Masses and the Class Struggle in Britain, Black Liberator, 2(3), June 1974/January 1975, p. 207.

45. Said, Edward. W. Culture and Imperialism. London: Chatto and Windus, 1994, p. 404; P. 403.

46. Chounara, Imitiaz. Trends in Youth Culture, Marxism Today, October 1974, p. 318.

47. International Affairs Committee, Racialism and "Black Power", CP/LON/RACE/O2/O1, LHASC.

48. Chounara (ref. 45, pp. 318-319)

49. Macdonald, Ian. The Capitalist Way to Curb Discrimination. Race Today, August 1973, p. 241.

50. Lloyd, Cathie. Antiracist Mobilization in France and Britain in the 1970 and 1980s, in Joly, Danièle. Scapegoats and Social Actors: The Exclusion and Integration of Minorities in Western and Eastern Europe. Houndmills: St Martin's Press, 1998, p. 159.

51. Lloyd (ref. 50, p. 159)

52. IS Central Committee. The Anti-Racialist Fight and the Right to Work Campaign, IS Post-Conference Bulletin, 1976, MSS.284, Alastair Mutch Papers, Modern Records Centre, University of Warwick.

53. Bogues, Tony. Black Youth in Revolt, International Socialism, 1(102), October 1977, p. 12.

54. Bogues (ref. 53, p. 13)

55. Rose, John. The Southall Asian Youth Movement. International Socialism, 1(91), September, 1976, p. 5 ; Italics are in the original text.

56. Rose (ref. 55, p.5)

57. Rose (ref. 55, p.6)

58. Cited in, Grewal, Shivdeep Singh. Capital of the 1970s? Southall and the Conjuncture of 23 April 1979, Socialist History, 23, 2003, p. 21.

59. Singh, Nermal. Racism: Time to Fight Back, Kala Tara [Online], (retrieved 14 March, 2007), 1, p. 3, (Url: http://www.tandana.org/pg/PDF/SC/SC2.PDF).

6o. Mehmood, Tariq. cited in Ramamurthy, A. Kala Tara - A History of the Asian Youth Movement. Lancaster: Second Generation Asians Resisting Racism Project, p. 14.

61. SWP Central Committee. The Riots and After, SWP Internal Bulletin, 4, 1981, MSS.284, Alastair Mutch Papers, MRC.

62. Crisis in the Inner Cities, Executive Committee Statement, 12-13 September, 1981, p. 1, CP/CENT/ CTTE/02/06, LHASC

63. Crisis in the Inner Cities. (ref. 62, p. 8)

64. SWP CC. (ref. 61); Italics are in the original text.

65. Sparks, Colin. A Class Riot Not a Race Riot, Socialist Review, May 1981, p. 7; Italics are in the original text.

66. Sparks, (ref. 65, p. 9)

67. Harman, Chris. The Summer of 1981: A Post-Riot Analysis, International Socialism, 2(14), Autumn 1981, p. $14 ;$ Italics are in the original text.

68. Harman (ref. 67, p. 15)

69. Harman (ref. 67, pp. 15-16) 
70. SWP CC. (ref. 61)

71. Harman (ref. 67, p. 40)

72. Cited in, The "Riots". Race \& Class, 23(2-3), Winter 1981-Autumn 1982, p. 225.

73. Cited in ref. 72, p. 239.

74. ref. 72, p. 232.

75. Cited in ref. 72, p. 231.

76. Cited in ref. 72, p. 236.

77. Kaye, Harvey J. The British Marxist Historians: An Introductory Analysis. Cambridge: Polity Press, 1984, pp. 229-230.

78. Hansard, 13 April, 1981, col. 29.

79. Webber, Frances. Six Centuries of Revolt and Repression, Race \& Class, 23(2-3), Autumn 1981-Winter 1982 , p. 245 .

8o. Joshua, Harris. \& Wallace, Tina. with Booth, Heather. To Ride the Storm: The 1980 Bristol "Riot" and the State. London: Heinemann, 1983, p. 12.

81. Cited in ref. 80, p. 12.

82. Rudè, George. The Riots in History, Marxism Today, October 1981, p. 23.

83. See: Race Today Collective. The Struggle of Asian Workers in Britain. London: Race Today, 1983, pp. 8-10.

84. Bhabha, Homi K. The Location of Culture, London: Routledge, 1994, p. 27; Italics are in the original text.

85. Bhabha (ref. 84, p. 26)

86. Bhabha(ref. 84, p. 26)

87. Bhabha (ref. 84, p. 25); Italics are in the original text.

88. See: Werbner, Pnina. Introduction: The Dialectics of Cultural Hybridity, in Werbner, Pnina and Modood, Tariq. Debating Cultural Hybridity: Multi-Cultural Identities and the Politics of Anti-Racism. London: Zed Books Ltd, 1997, pp. 1-26.

89. Ramamurthy (ref. 39, p. 47; p. 43)

90. Papastergiadis, Nikos. Tracing Hybridity in Theory, in Werbner \& Modood (ref. 88, p. 258)

91. Mahamdallie, Hassan. Black and White Lies, Socialist Review, January 2002, [Online], (Retrieved 28 January, 2010). (Url: http://www.socialistreview.org.uk/article.php?articlenumber=7809).

92. Kundnani, Arun. From Oldham to Bradford: The Violence of the Violated, Race \& Class, 43(2), October 2001, p. 105.

93. Kundnani (ref. 92, p. 11) 